\title{
IMPLICATIONS OF THE NEW 2019 HAGUE CONVENTION ON RECOGNITION AND ENFORCEMENT OF FOREIGN JUDGMENTS ON THE NATIONAL LEGAL SYSTEMS OF COUNTRIES IN SOUTH EASTERN EUROPE
}

\author{
Ilija Rumenov, PhD, Assistant Professor \\ University Ss Cyril and Methodius, Skopje, Faculty of Law "Iustinianus \\ Primus" \\ Bul. Goce Delcev 9, 1000 Skopje, N. Macedonia \\ i.rumenov@pf.ukim.edu.mk
}

\begin{abstract}
The diplomatic session of the Hague Conference on Private International Law (Hague Conference) regarding the "Judgments Project" will be held between 18 June - 02 July 2019 in the Hague when it is expected that the long awaited Hague Convention on Recognition and Enforcement of Foreign Judgments (new 2019 Hague Convention) will be adopted. This Convention comes as a result of 27 years of work that has been done in the course of this project of the Hague Conference and it can be said that is one of the most awaited developments in Private International Law. The success of the convention cannot be predicted at this point because large number of factors impact the outcome of the convention. However benefits from having an international agreement dealing with cross border recognition and enforcement of foreign judgments is self-evident. More than ever there is a need of a single instrument that will contain unified conditions for recognition and enforcement and ease the cross border circulation of judgments. Only a brief look at the New York Convention on recognition and enforcement of foreign arbitral awards (New York Convention) provides for glimpse of the benefits from having such instrument. So what will this mean for the countries of South Eastern Europe? What will be the interest of the countries to be part of this Convention? How much are the national legal systems compatible with the rules provided in the Hague convention?

This article will try to answer these questions, together with the implications that the Hague Convention will have on the South Eastern Europe region. Moreover this is of huge importance since most of the countries of South Eastern Europe region are part of the European Union or are candidate countries. So has the time come for a structural change of the national recognition and enforcement systems and how far reaching will be the consequences on the national legal systems?
\end{abstract}

Keywords: Hague Convention on Recognition and Enforcement of Foreign Judgments; Recognition and Enforcement; South Eastern Europe; civil and commercial matters; indirect jurisdiction; right of defense; public policy, irreconcilable judgments. 


\section{RECOGNITION AND ENFORCEMENT OF FOREIGN JUDGMENTS ACCORDING TO THE NEW 2019 HAGUE CONVENTION}

Recognition and enforcement of foreign judgments represents one of three basic components of private international law ${ }^{1}$ and therefore it is a very important part of the Hague Conference. ${ }^{2}$ However if we compare the international conventions adopted by the Hague Conference we can see the dominance of those which cover the conflict of law aspects ${ }^{3}$ and those regarding cross border cooperation ${ }^{4}$ over the other aspects of private international law (jurisdiction and exequatur). ${ }^{5}$ Such position is not a coincidence, because countries are more found in adopting rules which refer to the substantive law issues and are more resistant in adopting rules regarding procedural law issues. Moreover, in the case of recognition and enforcement this aspect goes further, because the exequatur represents last "defense" that legal systems possess regarding the incorporation of foreign judicial decisions in their domestic legal order.

On the other hand, transnational cooperation influenced by the globalization and the interconnection of the economic systems, asks for faster responsiveness of the legal systems and predictability of the legal outcome manifested by the judicial decisions. In other words there is a bias between sovereignty of the countries manifested in the rules for recognition and enforcement of judgments and the need for prompt cross border cooperation. Such antagonistic position had influenced the increased popularity of arbitration as an adjudicative system of "distribution of justice". The success that the New York Convention, created a "rivalry" between these two segments of the distribution of justice. The response of the judicial distribution of justice is the Hague Convention of recognition and enforcement of foreign judgments. The answer to the question whether this international convention will have

1 Together with conflict of law and international jurisdiction. See Fawcett J.; Carruthers J.; Cheshire, North \& Fawcett, Private International Law, Oxford University Press 14th ed., 2008, p. 7

2 On the structure of the Hague Conference see Droz L.A.G., A Comment On The Role Of the Hague Conference On Private International Law, Law and Contemporary Problems, 1994, Dyer A, The Hague Convention: Its Successes and Failures - Parts I and II; Australian Family Lawyer, June 1994, Vol. 9, and September 1994, Dyer A., To Celebrate a Score of Years!; New York University Journal of International Law and Politics, Vol. 33, Issue 1, 2000, Lipstein K., One Hundred Years of Hague Conferences on Private International Law, International and Comparative Law Quaterly, 1993, van Loon, J J.H.A., The Hague conference on private international law: an introduction', in: van Krieken, P.J.;McKay, M. (eds.), The Hague: Legal Capital of the World, The Hague, TMC Asser Press, 2005, van Loon, H.; Schulz, A., 'The European Community and the Hague Conference on Private International Law', in: Martenczuk, B.; van Thiel, S. (eds.), Justice, Liberty, Security: New Challenges for EU External Relations, Brussels University Press, 2008

317 Conventions

410 Conventions

510 Conventions 
success is complex and ambiguous, having in mind all of the economic and political developments in the world and the paste of the dynamics in today's economic environment. Lesson must be learned from the 1971 Hague Convention on Recognition and Enforcement of Foreign Judgments in Civil and Commercial Matters that the future of the new 2019 Hague Convention depends on the practicality of the adopted solutions and whether such rules are of interests to the countries.

\subsection{Scope of application of the new 2019 Hague Convention}

The scope of application of the new 2019 Hague Convention goes from general to specific, firstly determining the lager legal field of civil and commercial matters and then going to specific areas which are excluded from the scope of application. Article 1 of the new 2019 Hague Convention states that it applies to civil and commercial matters and then excludes the more specific areas such as tax, custom and administrative decisions from the scope of application. Article 2 goes into further specifics, containing claususlus numerus of the other areas which are excluded from the scope of application. ${ }^{6}$ Moreover, Article 2 of the new 2019 Hague Convention excludes the arbitral and other alternative dispute resolution decisions from the scope of application. Very important aspect of the new 2019 Hague Convention is that the convention is applicable towards civil and commercial judicial decisions in which one of the parties is a state, government, governmental institution or a person acting in the name of the state, but excluding the aspects regarding the immunity and the privileges of the states and international organizations.

\subsection{Recognition and enforcement of foreign judgments according to the new 2019 Hague Convention}

The new 2019 Hague Convention is intended to provide an effective system for recognition and enforcement of foreign judgments in civil and commercial mat-

6 The matters excluded from the new 2019 Hague Convention are: (a) the status and legal capacity of natural persons; (b) maintenance obligations; (c) other family law matters, including matrimonial property regimes and other rights or obligations arising out of marriage or similar relationships; (d) wills and succession; (e) insolvency, composition, resolution of financial institutions, and analogous matters; ( $\mathrm{f}$ ) the carriage of passengers and goods; (g) marine pollution, limitation of liability for maritime claims, general average, and emergency towage and salvage; (h) liability for nuclear damage; (i) the validity, nullity, or dissolution of legal persons or associations of natural or legal persons, and the validity of decisions of their organs; ( $\mathrm{j}$ ) the validity of entries in public registers; ( $\mathrm{k}$ ) defamation; [(l) privacy[, except where the proceedings were brought for breach of contract between the parties];] [(m) intellectual property [and analogous matters];] [(n) activities of armed forces, including the activities of their personnel in the exercise of their official duties; [ (o) law enforcement activities, including the activities of law enforcement personnel in the exercise of official duties;] [(p) anti-trust (competition) matters] 
ters and provide for circulation of judgments in circumstances that are largely considered to be uncontroversial. ${ }^{7}$ The mechanism established with the new 2019 Hague Convention provides that a judgment given by a court of a contracting state, shall be recognized and enforced in other Contracting state in accordance with the provisions provided in Chapter II of the new 2019 Hague Convention. ${ }^{8}$ Also this convention provides for the general principles according to which the for recognition and enforcement will be conducted, that there will be no revision au found ${ }^{9}$ and the condition that the judgment has effect and is enforceable in the country of origin. ${ }^{10}$

The system created by this convention is a simple one: if the judgment regarding civil and commercial matters is rendered in a country which satisfies the indirect jurisdictional grounds provided in Article 5 and if the grounds for refusal of recognition in Article 7 are not met, then the judgment can be recognized and enforced in a requested country. However, foreign judgments can be recognized and enforced under national law or other international convention, but with consideration to the exclusive bases given in Article 6 (which refer to exclusive bases of jurisdiction for registered intellectual property rights, rights in rem over immoveable property and tenancies of immoveable property).

The first criteria for circulation of judgments are provided in Article 5, which sets out the bases for recognition and enforcement of a judgment in the form of indirect jurisdictional grounds against which the judgment from the state of origin is to be assessed by the State where recognition and enforcement is sought. ${ }^{11}$ These grounds can be divided in three traditional jurisdictional categories: jurisdiction based on connection with the defendant, jurisdiction based on consent and jurisdiction based on connections between the claim and the state of origin. ${ }^{12}$ More specifically, this list contains jurisdictional bases such as: persons habitual residence is in the state of origin, ${ }^{13}$ natural persons had their principal place of business in the state of origin, ${ }^{14}$ person against whom recognition is sought is the person that brought the claim, ${ }^{15}$ defendant maintained a branch, agency or other

\footnotetext{
7 Garciamartin F, Saumier G., Preliminary document No 10 of May 2018 Judgments Convention: Revised Preliminary Explanatory Report, December, 2018, par. 16

8 Article 4 of the new 2019 Hague Convention

9 Article 4(2) of the new 2019 Hague Convention

10 Article 4(3) of the new 2019 Hague Convention

11 Garciamartin; Saumier, op. cit., note 7, p. 5, par 17

12 Garciamartin; Saumier, op. cit., note 7, p. 34, par. 146

13 Article 5(1)(a) of the new 2019 Hague Convention

14 Article 5(1)(b) of the new 2019 Hague Convention

15 Article 5(1)(c) of the new 2019 Hague Convention
} 
establishment without separate legal personality in the state of origin and the claim arose out of the activities of these entities, ${ }^{16}$ defendant expressively ${ }^{17}$ or tacitly ${ }^{18}$ consented to the jurisdiction of the court of origin, the judgment was given on contractual obligations and it was given in the State in which performance of that obligation took place according to the law that the parties choose or it was determined according to the conflict of law rules in that state (in absence of an agreed place of performance), ${ }^{19}$ the judgment is regarding a tenancy of immoveable property and it was given by a state where the property is situated, ${ }^{20}$ the judgment is regarding contractual obligation secured by a right in rem in immoveable property located in the state of origin, ${ }^{21}$ the act or omission directly causing harm occurred in the state of origin and a judgment on a non-contractual obligation was rendered in the state of origin, ${ }^{22}$ bases concerning trusts, ${ }^{23}$ counterclaims ${ }^{24}$ and choice of court agreements. ${ }^{25}$ Most of these grounds can be found in the national legal systems, but they are formulated more precisely or narrowly in the new 2019 Hague Convention. ${ }^{26}$ Moreover, there is no hierarchy between these grounds and satisfaction of a single ground can fulfill this condition. ${ }^{27}$

These grounds are limited by the exclusive jurisdictional rules listed in Article 6 (registered intellectual property rights, rights in rem over immoveable property and long term tenancies of immoveable property). In the cases where the judgments fulfills the requirements provided in Article 4, 5 and 6 the only grounds for refusal to recognize and enforce the decision are provided in Article 7. This list refers to grounds as: right of defense, ${ }^{28}$ the judgment was obtained by fraud, ${ }^{29}$ public policy, ${ }^{30}$ violation of choice of court agreement, ${ }^{31}$ inconsistency with a judgment

\footnotetext{
16 Article 5(1)(d) of the new 2019 Hague Convention

17 Article 5(1)(e) of the new 2019 Hague Convention

18 Article 5(1)(f) of the new 2019 Hague Convention

19 Article 5(1)(g) of the new 2019 Hague Convention

20 Article 5(1)(h) of the new 2019 Hague Convention

21 Article 5(1)(i) of the new 2019 Hague Convention

22 Article 5(1)(j) of the new 2019 Hague Convention

23 Article 5(1)(k)(i) and (ii) of the new 2019 Hague Convention

24 Article 5(1)(l) of the new 2019 Hague Convention

25 Article 5(1)(m) of the new 2019 Hague Convention

26 Garciamartin; Saumier, op. cit., note 7, p. 34, par. 146

$27 \quad i b i d$.

28 Article 7 (1)(a) of the new 2019 Hague Convention

29 Article 7 (1)(b) of the new 2019 Hague Convention

30 Article 7 (1)(c) of the new 2019 Hague Convention

31 Article 7 (1)(d) of the new 2019 Hague Convention
} 
given in the requested state ${ }^{32}$ and inconsistency with a judgment given in another state. 3334

Another rule provided in this article is given in Article 7(2) of the new 2019 Hague Convention, which establishes priority of the decisions which need to be recognized and enforced. In private international law legal theory ${ }^{35}$ in situation where there are conflicting proceedings the lis pendens rule applies. However, in the new 2019 Hague Convention there are no rules for direct jurisdiction and thus does not include a rule on lis pendens. ${ }^{36}$ The system developed in the new 2019 Hague Convention regarding parallel proceedings relies on Article 7(1)(e) and Article 7(1)(f) which deal with situations of inconsistency of the judgments given in the requested or given in another state and Article 7(2) which refers to situations when proceedings are still pending in the requested state and when recognition and enforcement of a judgment given in another state is sought. ${ }^{37}$ However, refusal under this paragraph does not prevent a subsequent application for recognition or enforcement of the judgment. ${ }^{38}$

Finally, the new 2019 Hague Convention introduces a favor recognitions principle according to which if judgment cannot be recognized and enforced on the basis of the new 2019 Hague Convention but it could be recognized and enforced according to the national legal rules then the requested state can recognize and enforce a foreign judgment based on national law. ${ }^{39}$ The only limitation of Article 16 of the new 2019 Hague Convention is that it does not apply to the three situations referred in Article 6 of the new 2019 Hague Convention (exclusive jurisdictional grounds). With such position it can be said that the intention of the new 2019 Hague Convention is to set out minimum standard for mutual recognition or enforcement of judgments. ${ }^{40}$

\footnotetext{
32 Article 7 (1)(e) of the new 2019 Hague Convention

33 Article 7 (1)(f) of the new 2019 Hague Convention

34 Another optional ground is the examination of the law applied by the court of origin in intellectual property matters is provided in Article 7 (1)(g). See more Garciamartin; Saumier, op. cit., note 7, p. 67-69, par. 303-312

35 Marongiu Buonaiuti, F., Lis Alibi Pendens and Related Actions in Civil and Commercial Matters within the European Judicial Area, Yearbook of Private International Law, vol.11, 2009, p. 513

36 Garciamartin; Saumier, op. cit., note 7, p. 68, par. 309

37 Ibid.

38 Article 7(2) of the new 2019 Hague Convention

39 Article 16 of the new 2019 Hague Convention

40 Garciamartin; Saumier, op. cit., note 7, p. 5 82, par. 367
} 


\subsection{Other provisions in the proposal of the Hague Convention on recognition and enforcement of foreign judgments}

The new 2019 Hague Convention contains other provisions that are in context of the system for recognition and enforcement. These aspect refer to questions such as: recognition and enforcement of preliminary questions,${ }^{41}$ recognition and enforcement of a severable part of a judgment, ${ }^{42}$ recognition and enforcement of damages including punitive damages ${ }^{43}$ and judicial settlements. ${ }^{44}$ Moreover the new 2019 Hague Convention contains rules that address procedural matters that facilitate access to the mechanism of new 2019 Hague Convention such as: documents that need to be produced, ${ }^{45}$ procedure ${ }^{46}$ and cost of proceedings. ${ }^{47}$

\section{IMPLICATION OF THE NEW 2019 HAGUE CONVENTION ON THE NATIONAL LEGAL SYSTEMS OF COUNTRIES IN SOUTH EASTERN EUROPE}

The system determined by the new 2019 Hague Convention for recognition and enforcement of foreign judgments is in three stages: first, if the judgment falls under the scope of application of the convention, secondly, if it satisfies one of the indirect jurisdictional bases and lastly, if it does not violate the grounds for refusal of the judgment than it can be recognized and enforced by the requested court. But this mechanism must be seen together with Article 16 of the new 2019 Hague Convention (favor recognitionis principle) which broadens the modalities upon which a foreign judgment can be incorporated in the domestic legal system by allowing implementation of national legal rules regarding recognition and enforcement if the decision cannot be recognized and enforced upon the new 2019 Hague Convention.

The first threshold that a foreign judgment needs to fulfill is that it has proper connections with the country of origin manifested in the form of the indirect jurisdictional grounds provided in Article 5 of the new 2019 Hague Convention. What is important for the national legal system is that these indirect jurisdictional grounds are irrelevant to the national direct jurisdictional rules. ${ }^{48}$ In the assess-

\footnotetext{
41 Article 8 of the new 2019 Hague Convention

42 Article 9 of the new 2019 Hague Convention

43 Article 10 of the new 2019 Hague Convention

44 Article 12 of the new 2019 Hague Convention

45 Article 13 of the new 2019 Hague Convention

46 Article 14 of the new 2019 Hague Convention

47 Article 15 of the new 2019 Hague Convention

48 Garciamartin; Saumier, op. cit., note 7, p. 34, par. 144
} 
ment of these indirect grounds the court of the requested state is not bound by the determination of the direct jurisdiction of the court of origin. For example, if the direct jurisdiction was determined by the N. Macedonian court on the bases of the domicile of the defendant ${ }^{49}$, the assessment whether the judgment of the N. Macedonian court fulfills the indirect jurisdictional requirements for recognition and enforcement according to the new 2019 Hague Convention can be determined according to the ground that the person against whom recognition is sought ${ }^{50}$ was habitually resident in the state of origin at the time that person became a party to the proceedings in the court of origin..$^{51}$ On the other hand if the person has domicile in N. Macedonia, but is habitually resident in another country, the judgment will has to fulfill other requirements provided in Article 5(1) of the new 2019 Hague Convention. Such relation between the direct and indirect jurisdiction of the country of origin and the requested country can produce an unsynchronized outcome. In this respect two possible approaches can be taken. Firstly, in short term, the application of Article 16 of the new 2019 Hague Convention which allows application of the national rules for recognition and enforcement provides for safe alternative. Secondly, on long term, this "passive" approach taken by the new 2019 Hague Convention, can influence the countries to synchronize the direct jurisdictional criteria with the criteria provided in the Article 5 of the new 2019 Hague Convention, which will have as an outcome easier circulation of judgments. ${ }^{52}$ For example, if the direct jurisdiction in N. Macedonia for legal person was determined on the ground that the principle place of business of the legal person was in N. Macedonia, this ground would correspond with the indirect jurisdictional criterion in Article 5(1)(a) of the new 2019 Hague Conven$\operatorname{tion}^{53}$ and if the other conditions of the convention are met the judgment would be recognized and enforced according to the new 2019 Hague Convention.

The new 2019 Hague Convention contains a specific provisions which expand the reach of the new 2019 Hague Convention on national law in three situations.

49 Article 51 of PILA of N. Macedonia. Private International Law Act of N. Macedonia (Закон за меѓународно приватно право на Република С. Македонија) (Official Gazette of the Republic of N.Macedonia (Службен Весник на РСM) no. 87/2007, 156/2010)

50 The phrase "person against whom recognition is sought" in Article 5(1)(a) of the new 2019 Hague Convention is intended to have broad number of persons against whom recognition and enforcement can be sought (e.g. claimant) and not to limit sub-paragraph (a) to one party (defendant). Garciamartin; Saumier, op. cit., note 7, p. 34, par. 149

51 Article 5(1)(a) of the new 2019 Hague Convention

52 Garciamartin; Saumier, op. cit., note 7, p. 34, par. 144

53 Article 3(2) of the new 2019 Hague Convention provides for a definition of habitual residence for entity or person other than natural person based on these criteria: statutory seat; formation or incorporation by law; central administration and principal place of business 
These situations are specified in Article 6 of the new 2019 Hague Convention and are given as exclusive bases for recognition with two effects: positive and negative. ${ }^{54}$ The positive effect provides for judgments that meet the bases of jurisdiction given in Article 6 can be recognized and enforced, while the negative effect provides for those which do not fulfill these criteria would not to be recognized and enforced under the new 2019 Hague Convention and under national law. ${ }^{55}$ The first situation refers to exclusive basis of jurisdiction for the recognition and enforcement of judgments on the (registration or) validity of intellectual property rights required to be granted or registered. ${ }^{56}$ These judgments shall be recognized if and only if the State of origin is the state in which grant or registration of the right concerned has taken place, or, under the terms of an international agreement or regional instrument, is deemed to have taken place. ${ }^{57}$ The second situation establishes an exclusive basis for recognition and enforcement of judgments that refer to rights in rem in immovable property. These judgments shall be recognized if and only if they were given by the courts where the immovable property is situated..$^{58}$ The third situation provides for exclusive jurisdiction for long term tenancies (longer than six months) but only if the law of the state where the immovable property is situated establishes such exclusive jurisdiction. ${ }^{59}$ All of these judgments must refer to these issues as the main object of the proceedings, while for preliminary or incidental issues there is another provision. ${ }^{60}$

Most of the national legal systems are familiar with these principles and provide for exclusive jurisdiction for these cases. The PILA of N. Macedonia in Article 67 provides for exclusive jurisdiction of the courts of N. Macedonia for registration and validity of industrial property rights if the application was filed in N. Macedonia. ${ }^{61}$ In addition to this, the court of N. Macedonia has exclusive jurisdiction over disputes relating to property rights on immovable property if the immovable

\footnotetext{
54 Garciamartin; Saumier, op. cit., note 7, p. 57, par. 256

55 ibid.

56 Article 6(a) of the new 2019 Hague Convention

57 Garciamartin; Saumier, op. cit., note 7, p. 57, par. 258. Difference must be made with Article 5(3)(a) of the new 2019 Hague Convention, where the nature of the dispute regarding these rights is different, namely Article 6(a) refers to registration or validity of these rights and Article 5(3)(a) refers to infringement of these rights

58 Article 6(b) of the new 2019 Hague Convention

59 Article 6(c) of the new 2019 Hague Convention

60 See Article 8 of the new 2019 Hague Convention

61 Article 67 of the PILA of N. Macedonia
} 
property is situated in the territory of N. Macedonia. ${ }^{62}$ Similar provisions are present in Bulgaria, ${ }^{63}$ Croatia, ${ }^{64}$ Montenegro, ${ }^{65}$ Slovenia, ${ }^{66}$ and Turkey ${ }^{67}$.

The second threshold of the new 2019 Hague Convention is that the recognition and enforcement can be refused if the foreign judgment doesn't fulfill the conditions laid down in Article 7(1) of the new 2019 Hague Convention. These seven conditions can lead to refusal of recognition or enforcement of a judgment in requested state but their application is not mandatory. The intention of the drafters was to create a minimum standards for refusal, however states may make adaptation of these conditions. ${ }^{68}$ Most of these conditions are not novelty and they can be found in the national legal systems.

The first condition refers to infringement of the right of defense in the state of origin. ${ }^{69}$ This condition specifically refers to the lack of proper notification to the defendant, which constitutes a ground for refusal of recognition and enforcement. ${ }^{70}$ In comparison with the PILA of N. Macedonia the rule provided in the new 2019 Hague Convention is more specific, providing for two distinct scenarios: first, that the document which instituted the proceedings or equivalent document, including a statement of the essential elements of the claim was not notified to

62 Article 69 of the PILA of N. Macedonia

63 Article 12 and 13(2) of the PILA of Bulgaria. Bulgarian Private International Law Act (Кодекс На Международното Частно Право, Обн. ДВ. бр.42 от 17 Май 2005г., изм. ДВ. бр.59 от 20 Юли 2007г., изм. ДВ. бр.47 от 23 Юни 2009г). English translation [http://solicitorbulgaria.com/index. php/bulgarian-private-international-law-code] Accessed 12.05.2015

64 Article 46 of the PILA of Croatia regarding jurisdictional issues in civil and commercial matters refers to application of the Regulation (EU) No 1215/2012 of the European Parliament and of the Council of 12 December 2012 on jurisdiction and the recognition and enforcement of judgments in civil and commercial matters in which in Article 24 an exclusive jurisdiction of the Croatian courts is provided if the immovable is located in Croatia. Zakon o međunarodnom privatnom pravu (Nar. nov., br. 101/17)

65 Article 119 and 122 of the PILA of Montenegro. Private International Law Code Montenegro (Zakon o međunarodnom privatnom pravu) (Official Gazette of the Republic of Montenegro, No 1/2014)

${ }_{66}$ Article 62 and 64 of the PILPA of Slovenia. Private International Law and Procedure Act (Zakon o mednarodnem zasebnem pravu in postopku), Official Gazette RS, no. 56/99

67 Article 12 Code of Civil Procedure (Law No.6100 of 12 January 2011), Official Gazette, 4 February 2011, No.27836. However the Turkish national legal system does not have an explicit rule regarding exclusive jurisdiction regarding registration and validity of industrial property rights. See, Beaumount P., Yüksel B., Turkish and EU Private International Law : A Comparison, Istanbul: XII Levha, 2014, p. 42

68 Garciamartin; Saumier, op. cit., note 7, p. 60-61, par. 273-275. According to this revised draft explanatory report, States may: (i) adopt domestic legislation that does not provide for refusal in some of these circumstances or provide for refusal in all these circumstances; (ii)require recognition and enforcement in some of these circumstances, or (iii) specify additional criteria that are relevant to the exercise of the discretion

69 Article 7(1)(a) of the new 2019 Hague Convention

70 Garciamartin; Saumier, op. cit., note 7, p. 61, par. 276 
the defendant in sufficient time and in such way as to enable him to arrange for his defence, unless the defendant entered an appearance and presented his case without contesting notification in the court of origin, provided that the law of the State of origin permitted notification to be contested; ${ }^{71}$ or second scenario, that the document which instituted the proceedings or equivalent document, including a statement of the essential elements of the claim was notified to the defendant in the requested State in a manner that is incompatible with fundamental principles of the requested state concerning service of documents. ${ }^{72}$ The PILA of N. Macedonia contains more general rule that refers to the violation of the right of defense as an obstacle for recognition and enforcement. This rule provides that the court of Republic of N. Macedonia shall refuse recognition of a foreign judgment, if one of the parties proves that: 1 . due to irregularities in the proceedings he had no opportunity to participate therein: or 2. the summons, the document or the ruling instituting the proceedings were not served upon him in a way provided by the law on procedure of the State in which the judgment was rendered, or if such service was not even tried, except when the party pleaded to the merits of the plaintiff's claim in the procedure of first instance. ${ }^{73}$

The wording of both of these rules is different, however several overlapping issues can be detected. First, both of these rules refer to the question of service of documents. The N. Macedonian rule starts from more general position to more specific, from existing irregularities in the proceedings which as consequence had prevented the party from participating, to the more specific aspect of service of documents. The new 2019 Hague Convention rule refers only to the question of service of documents. However, this rule must be read in conjunction with $\mathrm{Ar}$ ticle $7(1)(c)$ which refers to the public policy defense, but with specific reference of the "...fundamental principles of procedural fairness..." which on general level covers the issues such as right of the party to be heard, equity of arms and etc. ${ }^{74}$ Secondly, the standard upon which the service of documents is weight in the N. Macedonian PILA is the "... law on procedure of the State in which the judgment is rendered..." "Th. The approach taken in the new 2019 Hague Convention is different, in the first scenario there is no specific reference to the standard and whether the document instituting the proceedings was duly served on a defendant must be determined in the light of the provisions of the new 2019 Hague Convention and several modalities can be provided such as service to the employee of the

\footnotetext{
71 Article 7(1)(a)(i) of the new 2019 Hague Convention

72 Article 7(1)(a)(ii) of the new 2019 Hague Convention

73 Article 103 of the PILA of N. Macedonia

74 Garciamartin; Saumier, op. cit., note 7, p. 61, par. 279

75 Article 103 of the PILA of N. Macedonia
} 
defendant or public notice. ${ }^{76}$ However the right to be heard is not violated if the requested court is satisfied that all investigations required by the principle of diligence and good faith have been undertaken to trace the defendant without success. ${ }^{77}$ In the second scenario which is intended to protect the requested state, the issue is whether the defendant was notified in a manner that is incompatible with fundamental principles of the requested state concerning service of documents. ${ }^{78}$ Thirdly, in both rules the behavior of the defendant in the State of origin dictates its outcome, namely if the defendant entered in appearance and presented his case in the court of origin without contesting notification, the defense based on improper notification will not be available in the requested State. ${ }^{79}$

The legal obstacle provided in Article 96 of the Slovenian PILP act against the recognition and enforcement of a foreign judicial decision represents a negative condition and the Court examines it upon objection by the party. ${ }^{80}$ The second paragraph represents a presumption according to which the decision which was rendered in a process that consists of a violation of the rights of defense of the party against whom the recognition and enforcement is sought. Article 96(2) consists several in concreto 'scenarios' that have to exist in case a defense based on this provision is raised. The first type of scenarios refer to specific situations where the summons, the document or the ruling instituting the proceedings, was not served upon the person against whom enforcement is sought. The second type of scenarios is regarding the situations where service in personam was not even tried.$^{81}$ However, from the second sentence of the same paragraph it can be concluded that this presumption is rebuttable. ${ }^{82}$ In this case the burden of proof that the person has entertained proceedings on the merits in first instance shifts to the person who applied for recognition and enforcement. ${ }^{83}$ The Montenegrin PIL act contains a very similar rule, but it differs slightly by specifically referring to the scenario where the right of the defense was obstructed or denied to the party by

\footnotetext{
76 Garciamartin; Saumier, op. cit., note 7, p. 61, par. 280

77 ibid.

78 Article 7(1)(a)(ii) of the new 2019 Hague Convention

79 Garciamartin; Saumier, op. cit., note 7, p. 61, par. 279

80 Wedam Lukić D., Priznanje in izvršitev tujih sodnih odločb v Republiki Sloveniji, Pravni letopis, Inštitut za primerjalno pravo, Ljubljana, 2011, p. 135-136

81 In the PILA of N. Macedonia, the Slovenian approach was followed. However the in concreto scenarios were broadened with other scenarios such as'... if service in person was not even tried... ' aspect, but with difference in respect to the reference to the law according to which the service needs to be conducted ( ...in a way provided by the law on procedure of the State in which the decision was rendered...), Article 103(2) of the PILA of N. Macedonia

82 Dika M.; Knežević G.;Stojanović S., Komentar zakona o međunarodnom privatnom i procesnom pravu, Nomos, 1991, p. 291

83 ibid.
} 
not producing enough time for the preparation for the proceedings. ${ }^{84}$ The Bulgarian PIL act contains a more general rule where as a requirement for the protection of the right of defense, the defendant needs to be served with a copy of the statement of action, the parties need to be duly summoned and the fundamental principles of Bulgarian law related to defense of the parties must not be compromised. ${ }^{85}$ However, the defendant in the proceedings for recognition and enforcement of foreign judicial decision cannot invoke this violation if he could have raised it before the foreign court. ${ }^{86}$ The Croatian PIL act contains a more general rule and doesn't go in specific, simply stating that upon objection by the party, the Croatian court would refuse to recognize and enforce a foreign judgment if the party's right of participation in the proceedings was breached. ${ }^{87}$ The Turkish PILA in Article 54(d) also provides for this condition for recognition and enforcement of a foreign judgment.

The second condition in the new 2019 Hague Convention refers to fraud as ground for refusal of recognition and enforcement. ${ }^{88}$ This condition can be seen together with the third condition of the new 2019 Hague Convention which refers to public policy defense. ${ }^{89}$ Public policy has very broad meaning and its interpretation varies according to the national legal systems. Its scope and contents depend on the manner in which an individual state values its interests. ${ }^{90}$ This means that public policy or ordre public in Private International Law and Procedure can be understood as the sum of the values on which the legal, social and cultural order of a particular country depend and which must also be complied with in the socalled relationships with an international element. ${ }^{91}$

Slovenia in its PILP act does not contain a definition of public policy, but it states that the effect of the law (or the decision) must not be contrary to the Slovenian public policy. ${ }^{92}$ The position of Article 100 of PILP act of Slovenia accepts Lagarde's understanding that the legal norm of the foreign law does not by itself confront the domestic legal order itself, but only in correlation with concrete aspects of the do-

\footnotetext{
$84 \quad$ Article 143 (2) of the PIL act of Montenegro

85 Article 117 (2) of the PILA of Bulgaria

86 Article 120 (2) of the PILA of Bulgaria

87 Article 68 of the PILA of Croatia

88 Article 7(1)(b) of the new 2019 Hague Convention

89 Article 7(1)(c) of the new 2019 Hague Convention

90 Case II Ips 462/2009 of the Supreme Court of Republic of Slovenia, p.6-7, par. 9

91 Kramberger Škerl J., Evropeizacija javnega reda v mednarodnem zasebnem pravu, Pravni letopis, Inštitut za primerjalno pravo pri Pravni fakulteti v Ljubljani, Ljubljani, 2009, p. 349

92 See Articles 5 and 100 of the PILPA of Slovenia
} 
mestic legal order ${ }^{93}$. This means that the goal of the public policy is to 'remove the incoherency' in the interconnection of the foreign and domestic legal orders. ${ }^{94}$ Such an understanding of the public policy exception provides that the infringement must be in the context that the foreign legal norm by itself does not violate the public policy but only the effect of the foreign decision that it creates in context. ${ }^{95}$

Although the public policy has its own national characteristics regarding the structure of the rule, the PILA of N. Macedonia uses the same wording as the rule provided in the PILP act of Slovenia. ${ }^{96}$ The Bulgarian PIL act contains a simple rule regarding the public policy criterion. ${ }^{97}$ It just insists that the recognition and enforcement should not be contrary to Bulgarian public policy. Similar rule is contained in the Croatian PIL act ${ }^{98}$ and the Turkish PIL act. ${ }^{99}$ The Montenegrin PIL act has provided for a similar rule as the Slovenian PILP act where the requirement is that the foreign judicial decision will not be recognized in Montenegro if the effects of its recognition would be contrary to Montenegrin public policy. ${ }^{100}$ It is considered that this rule purpose is to establish substantive and procedural public policy in connection with effects with the forum. ${ }^{101}$

The forth condition refers to a judgment rendered by a Court that assumed the jurisdiction although there was a choice of court agreement which designated other Court than the court of origin. ${ }^{102}$ This conditions tends to uphold the prorogation iurisdicitonis and to respect the party autonomy. Article $7(1)(\mathrm{d})$ of the new 2019 Hague Convention needs to be seen together with the indirect jurisdictional bases given in Article 5 and it presents a last defense against a judgment that was rendered by a court that determined the jurisdiction on other bases, while a

${ }_{93}$ Kramberger Škerl J., Javni red pri priznanju in izvršitvi tujih sodnih odločb (s poudarkom na procesnih vprašanjih), Zbornik znanstvenih razprav - LXV. Letnik, 2005, p. 260

94 Lagarde P., Recherches sur l'ordre public en droit international privé, Paris, 1959, p. 174-188 (as cited by Varadi T. et al., Međunaodno privatno pravo, deseto izdanje, JP „Službeni Glasnik', Beograd, 2008, p. 158

95 Varadi et al., ibid., p. 159.

96 Article 107 of the PIL act of Macedonia

97 Article 117 (5) of the PILA of Bulgaria

98 Article 71 of the PILA of Croatia

99 Article 54(c) of the PILA of Turkey. Private International and Procedural Law Act of Republic of Turkey (Act No. 5718) (5718 sayılı Milletlerarası Özel Hukuk ve Usul Hukuku Hakkında Kanun) (Official Gazette in Turkey on 12 December 2007)

100 Article 147 of the PIL act of Montenegro

101 Kostić Mandić M., Recognition and enforcement of foreign court decisions in the new private international law of Montenegro, Collected papers, Association of Montenegro Lawyers, nos. 1-2/2015, p. 10

102 Article 7(1)(d) 
choice of court agreement was present in the case. ${ }^{103}$ The PILA of N. Macedonia also contains a condition for recognition and enforcement which refers to the infringement of a prorogation iurisdictions however, this rule is more limited and can be determined upon request by the parties against whom the foreign judgment was rendered and only in the case when the Court of N. Macedonia was designated with the agreement on jurisdiction. ${ }^{104}$ Article 98(2) of the Slovenian PILP act represents a safeguard of the parties' autonomy manifested in the jurisdictional agreement of jurisdiction of Slovenian courts. With this provision the Court, upon objection of a person against whom a foreign judicial decision was rendered, will refuse to recognize the foreign decision in the cases when the court rendering the decision failed to observe the agreement on jurisdiction of Slovenian courts. This condition is not considered ex officio, but on objection on the parties, namely the party against whom the recognition is sought. However, Bulgarian and Montenegrin PIL acts have not provided for this specific rule. Instead the Montenegrin PIL act has taken an indirect approach by providing that the choiceof-court-agreements have an exclusive jurisdictional character (if not otherwise determined by the parties $)^{105}$ and that the foreign judgments will not be recognized if the Court of recognition has exclusive jurisdiction. ${ }^{106}$ The Bulgarian PIL act gives an exclusive jurisdictional character to the choice-of-court-agreements, ${ }^{107}$ but fails to refer to exclusive jurisdiction as a condition for recognition. Instead it only provides for the 'mirror principle' rule as a condition for the recognition and enforcement of foreign decisions, stating that the judgments and authentic acts of the foreign courts and other authorities shall be entitled to recognition and enforcement where:

[t] he foreign court or authority had jurisdiction according to the provisions of Bulgarian law, but not if the nationality of the plaintiff or the registration thereof in the State of the court seized was the only ground for the foreign jurisdiction over disputes in rem. ${ }^{108}$

The effect of both approaches, the one taken in the Slovenian and the Macedonian PIL acts, and the other in the Bulgarian, Montenegrin PIL acts act, is the sameforeign judgments are not recognized if they violate the allowed and rightful parties' choice-of-court-agreement.

\footnotetext{
103 Garciamartin F, Saumier G., (n 7), p. 66, par. 297-298

104 Article 105(2) of the PILA of N. Macedonia

105 See Article 104 of the PIL act of Montenegro

106 See Article 144 of the PIL act of Montenegro

107 Article 23 and 24 of the PILA of Bulgaria

108 Article 117 (1) of the PILA of Bulgaria
} 
The fifth and the sixth conditions refer to two similar situations which resolve the problem of parallel proceedings. ${ }^{109}$ First, where the competing judgment was given by a court in the requested state, second where the competing judgment was given in another state (other than the court of origin). ${ }^{110}$ In the first case, the judgment from the country of origin is inconsistent with a judgment given in the requested state in a dispute between the same parties. ${ }^{111}$ The rule provided in this article is the same as the one in 2005 Hague Choice of Court Agreement Convention $^{112}$ and has two conditions: inconsistency between the judgments and dispute between the same parties. It does not require a temporal hierarchy and same cause of action. ${ }^{113}$ The second case applies where the judgment is inconsistent with an earlier judgment given another state between the same parties on the same subject matter, provided that the earlier judgment fulfills the conditions necessary for its recognition in the requested state. ${ }^{114}$ This rule is more specific than the last and contains more requirements to be applied. First, the judgment from the third state must have been given prior to the judgment from the state of origin, irrespective of which court was first seized. ${ }^{115}$ Secondly, both judgments need to be on the same subject matter. Thirdly, the earlier judgment must be eligible for recognition and enforcement in the requested state, whether or not that recognition or enforcement has been sought yet. ${ }^{116}$

Article 106 of the PILA of N. Macedonia refers to the question of irreconcilable judgments. These rules are modeled to protect the national legal system against irreconcilable judgments rendered in other legal systems on same subject matter (between same parties). As was the case with the other legal obstacles for recognition and enforcement in the PILA of N. Macedonia, Article 106 is also given as a negative one, meaning that a foreign judicial decision shall not be recognized if the court or another authority in N. Macedonia rendered a final decision on the same matter or if another foreign judicial decision rendered on the same matter was recognized in N. Macedonia. ${ }^{117}$ The court shall stay recognition of a foreign judicial decision in the cases when, before a N. Macedonian court, proceedings in the same legal matter and between the same parties, which were instituted earlier, are still pending

\footnotetext{
109 Article 7(1)(e) and (f) of the new 2019 Hague Convention

110 Garciamartin; Saumier, op. cit., note 7, p. 66, par. 300

111 Article 7(1)(e) of the new 2019 Hague Convention

112 Article 9(f) of the 2005 Hague Choice of Court Agreement Convention

113 Garciamartin; Saumier, op. cit., note 7, p. 67, par. 301

114 Article 7(1)(f) of the new 2019 Hague Convention

115 Garciamartin; Saumier, op. cit., note 7, p. 67, par. 301

116 ibid.

117 Article 106(1) of the PILA of N. Macedonia
} 
until the judgment in these proceedings become final. ${ }^{118}$ The determination of the existence of this legal obstacle is ex officio. Such a position of this Article refers to two different procedural situations. The first paragraph is referring to cases where in N. Macedonia the courts have already rendered a final judicial decision regarding the same matter or a foreign judicial decision has already been recognized in $\mathrm{N}$. Macedonia when a request for recognition is made. The second paragraph of the same Article is referring to cases where N. Macedonia courts have seized jurisdiction and proceedings are ongoing when request for recognition is made. The second situation is also covered in the new 2019 Hague Convention in Article 7(2). This rule allows the court of the requested state to postpone or refuse the recognition and enforcement if proceedings between the same parties on the same subject matter are pending before the court of the requested state and two additional criteria are met: first that the requested court was first siesed and second, there is close connection between the dispute and the requested state. ${ }^{119}$ Similar approach is taken in the Slovenian PILP act ${ }^{120}$ and Montenegrin PIL act ${ }^{121}$. The systematization of this rule in the Bulgarian PIL Act ${ }^{122}$ differs slightly. The rule provided in Article 117 (3) of the Bulgarian PIL act regarding the identity of the legal matter is the broadest because it covers not only legal matters between same parties in the same subject matter but also refers to the same facts. Nevertheless, the effect is the same regarding a decision which was rendered by the national court: this decision will have priority over the foreign judicial decision disrespectfully which proceedings were instituted earlier. On the other hand, when in front of the national court (Bulgarian) a foreign judicial decision is irreconcilable with other foreign judicial decisions, then the time plays important role. The Bulgarian rule provides that foreign judicial decisions will be recognized in Bulgaria if no proceedings based on the same facts, involving the same cause of action between the same parties, are brought before Bulgarian Court earlier than a case instituted before the foreign court in the matter of which judgment recognition is sought and the enforcement is applied has been rendered. ${ }^{123}$ The Bulgarian PIL act does not refer to the conduct of the Bulgarian Court when the first instituted concurrent proceedings have not been finished in Bulgaria.

The seventh condition in the new 2019 Hague Convention refers to the examination of the law applied by the court of origin in intellectual property matter. ${ }^{124}$

\footnotetext{
118 Article 106(2) of the PILA of N. Macedonia

119 Article 7(2) of the new 2019 Hague Convention

120 Article 99 PILP act of Slovenia

121 Article 146 of the PIL act of Montenegro

122 Article 117 (3) and (4) of the PILA of Bulgaria

123 Article 117 (4) of the PILA of Bulgaria

124 Article 7(1)(g) of the new 2019 Hague Convention
} 
This rule is present in the draft text of the new 2019 Hague Convention, but its future is still debatable and its application will depend on the outcome of the diplomatic session. Such rule is not present in PILA of N. Macedonia, Slovenia, Montenegro and Bulgaria.

\section{CONCLUSION}

The new 2019 Hague Convention will represent an important step forward in the circulation of judgments between countries. The cautious approach taken by this latest instrument deployed by the Hague Conference, can have short and long term impact on the countries. On short term it will attract them to sign this international instrument because of the 'minimum standard' approach taken by the new 2019 Hague Convention. More importantly, this Convention can produce long lasting consequences with the possible approximation of the national legal systems with the principles provided in the convention. The fact that the person seeking recognition can opt whether to use the procedure laid down in the convention, or the national legal rules for recognition and enforcement (or both) provides for more "exequatur friendly" legal environment and existence of minimum standards in the countries. This can bring together different legal cultures and have transnational (transcontinental) consequences. Such approach is more than welcomed.

The system presented in the new 2019 Hague Convention is a simple one with several steps which need to be taken. First the scope of the application of the convention is 'sketched' in details and predicted to cover the most crucial aspects of civil and commercial matters which can be viewed as uncontroversial. Moreover the fact that the main obstacle of the "Judgment Project" was solved and the rules for direct jurisdiction were left out of the convention does not represent a step back from the main idea of judicial co-operation, with view the enhancing predictability and justice in cross border legal relations in civil and commercial matters. The indirect jurisdictional rules in the new 2019 Hague Convention do not compete with the national jurisdictional criteria, but in a long run the criteria in the Convention can have an impact on the national direct jurisdictional criteria and with that they can fulfill the main goal of the convention. Very important aspect of the new 2019 Hague Convention are the exclusive basses for jurisdiction, however these grounds should not represent much of a problem since they are present in most of the national legal systems. The grounds for recognition are also flexible, they can be applied in several modalities with the national conditions for recognition and enforcement. The conditions for recognition in the new 2019 Hague Convention are given in more specifics than the national legal rules. This is also an advantage because of the more specific drafting of the condition 
for recognition and enforcement in the new 2019 Hague Convention, they can complement the national legal rules on exequatur.

Regarding the implication of the Hague Convention in the region of South East Europe it can be said that the implementation would not cause serious obstacles on the national legal system especially because of the liberal approach taken by the new 2019 Hague Convention regarding the application of national legal rules, other international agreements and EU regulations. Most of the solutions provided in the new 2019 Hague Convection are known in the national legal systems and correspond with the national legal standards. It is very important for these countries to invest in facilitation of this new instrument because as the trade goes further in the west, but more importantly in the east, this instrument can have long lasting consequences for the legal certainty, procedural predictability and in the end for the economy of the region.

\section{REFERENCES}

\section{BOOKS AND ARTICLES}

1. Beaumount P.; Yüksel B., Turkish and EU Private International Law : A Comparison, Istanbul: XII Levha, 2014

2. Fawcett J.; Carruthers J.; Cheshire, North \& Fawcett, Private International Law, Oxford University Press 14th ed., 2008

3. Garciamartin F.; Saumier G., Preliminary document No 10 of May 2018 Judgments Convention: Revised Preliminary Explanatory Report, December, 2018

4. Dika M.; Knežević G.; Stojanović S., Komentar zakona o mecunarodnom privatnom i procesnom pravu, Nomos, 1991

5. Droz L.A.G., A Comment On The Role Of the Hague Conference On Private International Law, Law and Contemporary Problems, 1994

6. Dyer A, The Hague Convention: Its Successes and Failures - Parts I and II; Australian Family Lawyer, June 1994, Vol. 9, and September, 1994

7. Dyer A., To Celebrate a Score of Years!', New York University Journal of International Law and Politics, Vol. 33, Issue 1, 2000

8. Kostić Mandić M., Recognition and enforcement of foreign court decisions in the new private international law of Montenegro, Collected papers, Association of Montenegro Lawyers, nos. $1-2 / 2015$

9. Kramberger Škerl J., Javni red pri priznanju in izvršitvi tujih sodnih odločb (s poudarkom na procesnih vprašanjih), Zbornik znanstvenih razprav - LXV. Letnik, 2005

10. Kramberger Škerl J., Evropeizacija javnega reda v mednarodnem zasebnem pravu, Pravni letopis, Inštitut za primerjalno pravo pri Pravni fakulteti v Ljubljani, Ljubljani, 2009

11. Lagarde P., Recherches sur l'ordre public en droit international privé, Paris, 1959 
12. Lipstein K., One Hundred Years of Hague Conferences on Private International Law, International and Comparative Law Quaterly, 1993

13. Marongiu Buonaiuti, F., Lis Alibi Pendens and Related Actions in Civil and Commercial Matters within the European Judicial Area, Yearbook of Private International Law, vol.11, 2009

14. Varadi T., et al., Mecunaodno privatno pravo, deseto izdanje, JP „Službeni Glasnik', Beograd, 2008

15. van Loon J J.H.A., 'The Hague conference on private international law: an introduction', in: van Krieken, P.J.; McKay, D., (eds.), The Hague: Legal Capital of the World, The Hague, TMC Asser Press, 2005

16. van Loon, H.; Schulz, A., 'The European Community and the Hague Conference on Private International Law', in Martenczuk, B.; van Thiel, S. (eds.), Justice, Liberty, Security: New Challenges for EU External Relations, Brussels University Press, 2008

17. Wedam Lukić D., Priznanje in izvršitev tujih sodnih odločb v Republiki Sloveniji, Pravni letopis, Inštitut za primerjalno pravo, Ljubljana, 2011

\section{EU LAW}

1. Regulation (EU) No 1215/2012 of the European Parliament and of the Council of 12 December 2012 on jurisdiction and the recognition and enforcement of judgments in civil and commercial matters, OJ L 351, 20.12.2012, p. 1-32

\section{LIST OF NATIONAL REGULATIONS, ACTS AND COURT DECISIONS}

1. Case II Ips 462/2009 of the Supreme Court of Republic of Slovenia

2. Code of Civil Procedure of Republic of Turkey (Law No.6100 of 12 January 2011), Official Gazette, 4 February 2011, No.27836

3. Private International Law Act of Republic of Bulgaria (Кодекс На Международното Частно Право, Обн. ДВ. бр.42 от 17 Май 2005г, изм. ДВ. бр.59 от 20 Юли 2007г., изм. ДВ. бр.47 от 23 Юни 2009г). English translation [http://solicitorbulgaria.com/index.php/bulgarian-private-international-law-code] Accessed 12.05.2015

4. Private International Law Act of Republic of Croatia (Zakon o međunarodnom privatnom pravu (Official Gazette of Republic of Croatia "Narodne Novine” 101/17)

5. Private International Law and Procedure Act (Zakon o mednarodnem zasebnem pravu in postopku), Official Gazette RS, no. 56/99

6. Private International Law Act of N. Macedonia (Закон за меѓународно приватно право на Република С. Македонија) (Official Gazette of the Republic of N.Macedonia (Службен Весник на РСM) no. 87/2007, 156/2010

7. Private International Law Act of Republic of Montenegro (Zakon o međunarodnom privatnom pravu) (Official Gazette of the Republic of Montenegro, No 1/2014)

8. Private International and Procedural Law Act of Republic of Turkey (Act No. 5718) (5718 sayılı Milletlerarası Özel Hukuk ve Usul Hukuku Hakkında Kanun) (Official Gazette in Turkey on 12 December 2007) 